\title{
Legal Politics of Land Rights Certification in The Indonesian Context: Between Agrarian Conflicts and Demands for Legal Certainty
}

\author{
Putu Gede Arya Sumerta Yasa*, Kadek Agus Sudiarawan, Putri Triari Dwijayanthi and \\ Made Dandy Pranajaya
}

\author{
Faculty of Law, Universitas Udayana, Bali, Indonesia
}

\begin{abstract}
This writing aims to analyze and identify the legal regulations and politics of registration (certification) of land rights in the context of Indonesian land law, particularly in Law No.5 of 1960 on Basic Agrarian Regulations (UUPA) amidst various agrarian conflicts and legal certainty documents over land rights that occur in Indonesia. This research will also seek to find comparisons that regulate and the politics of registering land rights in other countries. This is a normative legal research method with a statute approach and a comparative law approach. The results of the research show that the UUPA is a legal product in the field of agriculture that is unification for all Indonesians which is a mandate of the provisions of Article 33 paragraph (3) of the 1945 Constitution of the Republic of Indonesia. Various agrarian conflicts that occur in Indonesia are caused by problems with land titles. Legal certainty through the certification of land rights is the answer to what agrarian law politics wants, considering that to create agrarian politics that makes people prosperous, protection of the rights inherent in land is needed. Through a clear foundation of rights will be able to increase economic value for landowners and improve the welfare of the Indonesian people at large. The regulation and politics of land registration law in several other countries such as Singapore, Malaysia, Mexico and Ethiopia also show the certification of land rights as an effort to provide protection and legal certainty for land that is used for community welfare.
\end{abstract}

Keywords: Legal Politics, Certification, Land right, Agrarian Conflict, Comparative Study.

\section{INTRODUCTION}

Land as one of the agrarian resources has a very important role in human life (Silviana 2012). Land is a vital asset to both individuals and communities around the world (Human Rights Watch n.d.). Both land and humans in life are inseparable things, human dependence can be observed in the economical, cultural, political, and social fields. The need for land is one of a basic needs because the land has a high position and value for human life, namely as a place for humans to be born, raised, build their life as a place to live, as a source of income and is also needed even when they die (Herrayani, Soraya, and Mocthar 2019). The need shows that the land problem is a fundamental problem for everyone (Syahri 2014).

Land as a source of life in its management must pay attention to and follow established guidelines in the form of positive law and natural law, so that the sustainability of human life is maintained.

The dependence of humans on land, especially in fulfilling welfare, causes problems with the object of land, both between individuals and individuals and with state institutions or civil institutions. According to Lukman Soetrisno, there are three kinds of human dependence on land, inter alia (Soetrisno 1995):

*Address correspondence to this author at the Faculty of Law, Universitas Udayana, Bali, Indonesia; E-mail: arya_sumerthayasa@unud.ac.id a. Human needs land to gain income to support their daily needs;

b. Human needs land to build their house to live;

c. Human need land as their graves.

Based on data from the Ombudsman of the Republic of Indonesia for the last 3 years, it shows nationally that the substance of land has never been absent, occupies the top position as the substance most frequently reported by the public (William Benu 2020). Agrarian problems in Indonesia mostly influenced by political, economic, and military powers that can work together to utilize various sectoral laws in the agrarian sector/natural resources to form several oligarchs of political and economic power ( $L$ Purwaka 2016).

In Indonesia, the local land offices face a challenging task in term of spatial and legal data collection for systematic land titling projects. It is not easy for them to collect and verify the required documents completely, especially when it comes to the pluralism inherent to the underlying land tenure structure (Aditya et al. 2020).

The Ministry of Agrarian Affairs and Spatial Planning/State Land Agency (hereinafter ATR/BPN) noted that until October 2020, conflict disputes and court cases regarding land were 9,000 cases (Fadli 
2020). According to the Minister of ATR/BPN Sofyan Djalil, the process of resolving land conflict is very important to be completed to provide legal certainty to the community regarding the problematic land (Al Bahriyatul Baqiroh 2019).

The number of land-related conflicts that occur in Indonesia is due to the uncertainty of land laws in Indonesia. This shows that the national land management system still needs improvement. Currently, the two basic elements that become problems in various land cases in Indonesia are related to welfare and the legal certainty of its rights.

The number of land-related conflicts that occur in Indonesia is due to the uncertainty of land laws in Indonesia. This shows that the national land management system still needs improvement. Currently, the two basic elements that become problems in various land cases in Indonesia are related to welfare and legal certainty of land rights (BAPPENAS 2013). In Indonesia, only $46 \%$ of all land in Indonesia is certified except for forest areas, and by 2025 it is targeted that all land in Indonesia has been registered and certified (Wicaksono 2019).

In terms of land issues in Indonesia, the Finance Ministry expects all the land owned by the government to be registered and certified by 2022 as an effort to protect state assets and avoid a legal dispute. The report shows that around 46,725 tracts of land covering about 275,000 hectares have not been certified (Wardhana 2020).

So far, in the land bureaucracy, it happened that there are many irregularities in land rights registration services as well as other irregularities. Discrimination of bureaucratic services against control, ownership, use, and utilization as well as granting of rights to land, discrimination which usually occurs between officials, businessman and small people is still very often found in the Indonesia land bureaucratic (Handoko 2011).

Conflicts in land use between various development sectors due to increasing population, scarcity of land and deteriorating quality which causes poverty, narrow employment opportunities and unequal access to the acquisition of land use and increasingly forced rights of indigenous peoples

Conflicts in land use between various development sectors due to increasing population, scarcity of land and deteriorating quality which causes poverty, narrow employment opportunities and unequal access to the acquisition of land use and increasingly forced rights of indigenous peoples (Sumardjono 2006). Several land conflicts that have occurred in Indonesia have left many concerns in the form of property and death, namely the case in Lampung in Pelita Jaya hamlet, Mesuji village, between transmigrants and the company (Mesuji conflict) (Anggriawan 2011), the mining land case in Donggala, South Sulawesi (Paino 2015), as well as grave land disputes (known as setra) between villages in Bali (Tirthayasa 2013). Most of the time, the problem that happen in the society causes by the absence of land certification. In Bali, the matter of land issue usually managed by Balinese traditional community, named Desa Pakraman or Desa Adat (Triari, Jones, and Satyawati 2017). The conditions of this regulation have implications for hampering efforts to launch programs to accelerate development and increase community welfare (Chopra 2015).

If a research is carried out on land disputes in Indonesia, it can be assumed that there are various types of land disputes in almost every district, such as: land disputes proven by pipillpetuk/tax payment letters/absolutely no evidence only by controlling the land, disputes that both have certificate of land (double certificate), land dispute between certificate owners and proof of land distribution. Several problems arises indicate that the land which is the surface of the earth has not been able to give the maximum benefit for the prosperity of the people (Hajati et al. 2020).

The land conflicts recorded in Indonesia are generally caused by the absence of legal certainty because land is not yet certified. Legal protection and guarantee of legal certainty in the field of land means that every Indonesian citizen can control land safely. Land ownership is a human right that is protected by international law and national law (Djanggih and Salle 2017).

The state is given the authority to regulate, as well as carry out the designation, use and maintenance of natural resources with the aim of providing welfare to the community. Moving on from the several problems mentioned above, it becomes very interesting to dissect more deeply related to the regulation and politics of registration (certification) of land rights in the context of Indonesia land law, especially in Law No. 5 Year 1960 concerning Basic Agrarian Principles (hereinafter UUPA) and how the comparison of legal regulations and land rights registration in several other countries. 
Internationally, there is no declaration or treaty that specifically stipulated human right to land (Gilbert 2013). Land rules are not a shapeless jumble, but instead form an unauthored strategy which allocates a resource with extremely complex attributes (Ellickson 1993). A new insight regarding the design and implementation of land registration systems is needed to serve people better and even provide benefit for human life (Roux 2013). The importance of law-idea as a basis and binding in the process of forming legislation including legislation relating directly to social welfare (Lindbeck 2006).

\section{RESEARCH METHOD}

This is a normative legal research by imagining that law is the prescriptive discipline (Choudhury 2017), focusing on law as a norm or a system of norms or hierarchy of laws and regulations (Petroski 2015). This legal research uses a statutory approach, which examines the regulations and politics of legal registration (certification) of land rights in the contexr of Indonesian land law, especially in Law No. 5 Year 1960 on Basic Agrarian Principles, the 1945 Constitution of Indonesia, Government Regulation No. 10 Year 1961 concerning Land Registration and comparative approaches by conducting a comparative study of law with legal arrangements in several other countries. The results of this study are presented in an analytical descriptive scientific paper.

\section{RESULTS AND DISCUSSION}

\section{Legal Politics of Land Certification in the Context of Indonesian Land Law}

Land is one of the main capitals in national development, both as a forum for implementing national development and as a production factor in order to increase national income (Hajati et al. 2020). Land is an asset as well as a capital for non-economic development, both of which form a unit where there are humans as residents and the content of natural resources in it (Rahmi 2010).

In Indonesia, the dissecting about certification of land rights cannot be separated from Law Number 5 of 1960 concerning Basic Agrarian Principles (hereinafter UUPA), that referred on the Article 33 paragraph (3) of the 1945 Constitution of the Republic of Indonesia (hereinafter the 1945 Constitution of Indonesia). The scope of agrarianism in the UUPA included earth, water, space, and natural resources contained therein. The scope of earth includes the earth's surface (land), the body of the earth, and the space under the water's surface. Thus, land is a part of agrarianis. In accordance with Article 33 paragraph (3) of the 1945 Constitution of Indonesia, as a constitutional basic for regulating natural resources, is a norm of authority (bevoegdheids-norm), which has given the legal mandate to the State to take legal actions against natural resources (Muhammad 2015).

The UUPA, which was promulgated on September 24,1960 , was a legal product in the field of agriculture which was unification for all Indonesians and revoked the Agrarian provisions in the Dutch East Indies era, especially the domineering principle. The revocation of the domineering principle can be observed in the answer to the draft of the UUPA which Mr. Sadjarwo as Minister of Agrarian Affairs at that time was as follows:

"In addition to overthrowing the peak of the splendor of foreign capital, which has squeezed the wealth and energy of the Indonesian nation for centuries, whis bill should put an end to land disputes and disputes between the people and foreign businessman, and their apparatuses who tattle government apparaturs with their people, which triggered bloody events and repeated grievous practices" (Parlindungan 1997).

In accordance with Article 33 paragraph (3) the 1945 Constitution of Indonesia ensure that the used of Land for the welfare of people in which managed and regulated by government, the Article 2 of the UUPA stipulated that the concept of being managed by the States shall regulate the use, supply and maintenance of earth, water, and space, including the relationship between people and its surrounding and regulate the legal relationship between people and legal actions in terms of the use of earth, water, and space.

The meaning of regulating the State regarding the earth, water, and space was reaffirmed by the issuance of the UUPA, which regulates the issue of justice in Indonesia. With the enactment of the UUPA, there was the revocation of the provisions for land products of the Dutch East Indies that were previously in effect, namely revoking:

1. Agrarische wet (S $1870-55$ ) as stated in Article 5 "Wet op de Staatsinrichting Van Nederlandsch Indie" (Staatsblad 1925 No.447 and other provisions); 
a. Domeinverklaring based on Article 1 Agrarisch Besluit (S. 1870 no.118)

b. Algemeen Domeinverklaring (S. 1875 No.119a)

c. Domeinverklaring Sumatera based on Article 1 Staatsblad 1874 No.94f

d. Domeinverklaring Menado based on Article 1 Staatsblad 1877 No. 55

e. Domeinverklaring untuk Residentie Zuider en Oosterofdeling van Borneo based on Article 1 Staatsblaad no 58

2. Koninlijk Besluit Staatsblaad No. 117

3. Book II of the Indonesian Civil Code insofar as it concerns the earth, water, and natural resources contained therein, except for the provisions regarding the hypotheek which are still in effect when this law comes into effect.

With the revocation of the agrarian provisions characterized by the Dutch East Indies, agrarian law was enacted, which were a product of the Indonesian government with the following characteristics (Parlindungan 1997):

1. Has a unitary principle for the entire territory of the State of Indonesia;

2. Deletion of the domein statement;

3. Has a social function;

4. Recognition of customary law;

5. The equality of fellow citizens;

6. Reforming human relations with land;

7. General plan for the use, supply, maintenance of earth, water, and space;

8. The principle of nationality.

Based on the principles abovementioned, the UUPA reaffirms that the abolition of the domineering principle that places the State as controller of the land by making arrangements, through Article paragraph (3) of the 1945 Constitution of Indonesia, which is further elaborated in Article 2 paragraph (1); (3); and (4) those who want the State as an organization of power to be granted the right to control (not own) the earth, space water, and natural resources contained therein by increasing the welfare and prosperity of the people, nationality, as well as the authority to control is empowered to autonomous regions and customary law communities, which do not conflict with national interests according to the provision of the Government Regulation. The UUPA as the basis for regulating land rights only regulates matters that are basic in nature, so that some implementing provisions are ordered to be re-regulated by organic legislation, by laws, government regulations and ministerial regulations (Ginting 2011).

The legal politic shows the existence of certain state laws and embodies the nuances of people's lives (Rahman and Baso Madiong 2017).

The politics of land comes from the needed of land by humans in the present area that cannot be denied (Amiludin 2018). The politics of land law are government policies in the field aimed at the designation and use of the rulel or land owner that aims to protect the rights of land and its fuctions as enacted on the Land Law and its implementing regulations (Sulistio 2020). The control and use of land as regulated in the UUPA is the direction of Indonesian land law politics which aims to ensure the realization of prosperity for all Indonesian. It can be seen from the special attention to weak community group through land policies (Ismail 2012).

In the various existing literatures on Agrarian Affairs in Indonesia, it can be found that legal policies are the lines of official policies of a State or a will of the rulers of the State to be set forth in the form of law to achieve the goals of the State. Regarding the objective of the State, it can be observed in Pancasila and the 1945 Constitution of Indonesia, so that all legal products that are born must be guided by Pancasila as the ideology and the 1945 Constitution of Indonesia as the basis of the State.

As stipulated in Pancasila and the 1945 Constitution of Indonesia, the UUPA provides a basis for the State to make arrangements for land, starting with the arrangement of ownership of land rights in terms of land ownership, the UUPA emphasizes more on the aspect of its ownership. The UUPA has regulated the ownership of land rights through land registration based on Article 19 paragraph (2) of the UUPA that land registration includes:

1. Measurement, mapping and bookkeeping of land; 
2. Land rights registration and the transfer of the rights;

3. Giving letters of proof of rights that considered as valid.

According to Article 19 paragraph (2) it is concluded that if someone carry out land registration there are steps that must be followed, starting from measuring, to providing proof of rights as land title certificates. Based on Article 1 of Government Regulation No. 24 Year 1997 regarding Land Registration, which is implementing regulation of the UUPA, that mention:

"Land registration is a series of activities carried out by the Government constantly, continuously and regularly, including the collection, processing, bookkeeping, and presentation and maintenance of physical and juridicial data, in the form of maps and lists, regarding land parcels and house units, stacking, including the issuance of certificates of proof of their rights for land parcels for which there are already rights and ownership rights to apartment unites and certain rights that impose them".

Moving on from the definition above, "series" describes a gradual process between one activity and another that can provide data certainty about land. It continually requires activities carried out by the government until there are valid physical and juridicial data. Any information regarding location, boundary and area of a plot of land, as well as a list of apartment unit, including information regarding the existence of a bulding or part of the building on it, is considered as "Physical Data". Meanwhile, any information regarding the legal status of land and a registered apartment unit, its right holder and the rights of other parties as well as other burdernsome burden called "Juridicial data".

In the land registration process, it can be observed from the time of registration that it can be divided into two, namely the first time of land registration (known as "adjudication") and maintenance of land registration data carried out in the next transfer of rights. Adjudication known as an activitiy carried out in the land registration process that includes collecting and determining the correctness of both physical and juridicial data in terms of land registrations objects for registration purposes.

The registration of land is carried out on land registration objects that have not been registered under
Government Regulation No. 10 Year 1961 concerning Land Registration. Land registration is discussed from the object, the registered area is divided into "systematic land registration", which registered land for the first time carried out simultaneously which includes all objects of land registration that have not been registered in the territory or part of the territory of a village or sub-district which is organized by the Minister based on the work plan and implementation in the areas stipulated by the government and the region are made, while sporadic registration is the activity of registering land for the first time regarding one of several objects of land registration in an area or part of a village or sub-district area individually or in bulk (Harsono 1994). In the sporadic and systematic process of land registration, the registration activity is carried out with several steps, namely:

1. Collecting and processing physical data;

2. Proof and rights and bookkeeping;

3. Issuance of certificates;

4. To provide physical and juridicial data;

5. Storage of public registers and documents.

Land that has been registered in the event of a transfer of rights will be processed in the data maintenance and registration land whose activities include:

a. Transitional registration and loading;

b. Registration of other land registration data changes.

For the first time land registration can be done systematically and sporadically by collection gand processing data, through measuring and mapping activities carried out by making a registration base map which includes:

1. Determination of land parcel boundaries;

2. Measurement and mapping of land parcels and preparation of registration maps;

3. List of land;

4. Making a measuring letter.

The boundary determination of land parcels, in order to fulfill the physical data required land 
registration, is carried out by measuring its location, boundaries, and according to the need it is determined by boundary markers in each corner of the land parcels concerned by means of an agreement of the parties concerned.

Land registration recognizes several systems, inter alia, the Torrens system, in this system it is clear that the authority of the official through the challenges of the last official and owner contained in each transfer. This system is simple and inexpensive, and guarantees greater certainty.

However, there is a weakness in the system of negative land registration which other people can deny someone's ownership of the land. This weakness can be observed in Article 19 paragraph (2) and Article 32 paragraph (1) of the Government Regulation Number 24 Year 1997 (hereinafter PP No. 24 Year 1994), which stipulates that certificate can be used as a valid proof of right if all the physical and juridicial data are in accordance with the data contain in the relevant measuring letter and land book.

Strong evidence means that the certificate has strong evidence when compared to other evidence, for example, a tax certificate on land objects, which considers as a not-absolute evidence. Registration of land rights with a positive system, namely a system of land registration which requires that what is stated on the certificate is inviolable, this system is the opposite of negative registration. Negative system of land registration is a system of registering land rights where the correctness of the data contained in the certificate does not apply absolutely so that the opportunity for other parties to dispute is given to the court.

Indonesia adopts a mixed system in term of land registration, namely a negative registration system with a positive tendency. It explains that someone who is recorded on the certificate is valid as long as no one else can prove otherwise.

Based on Article 19 paragraph (1) of the UUPA, it is determined that the purpose of land registration is to ensure the legal certainty by helding land registration by the Government as stipulated in a Government Regulation. The purpose of land registration is clearly stated in Article 3 of PP No. 24 Year 1997, inter alia: to provide legal certainty and legal protection as well as providing correct information for the government and other related parties, and also for the implementation of an orderly land administration.
The legal certainty of a certificate is the answer to what agrarian legal politics wants, because in realizing agrarian politics that makes the community prosperous, it is necessary to protect the rights inherent in the land, on the basis of clear rights that will provide economic value to land owners. The legal certainty of land title certificates is stated in Article 32 of PP No. 24 Year 1997 which stated:

1. It is valid as a strong means of proof regarding the physical data dan juridical data contained therein, is in accordance with the data contained in the measuring document and land title book concerned.

2. In the case of a land parcel where a legal certificate has been issued in the name of the person or legal entity who acquired the land in good faith and actually controls it, then the other party who feels that he has rights to the land can no longer demand the exercise of that right, if within 5 (five) years from the issuance of the certificate, the certificate holder and the head of the relevant Land Office have not submitted a written objection of have not filed a lawsuit to the Court regarding land control or the issuance of the certificate.

The will of the State in term of certification then issued a Regulation of the Minister of Agrarian and Spatial Planning/Head of the National Land Agency No. 12 Year 2017. One of the considerations is to accelerate social welfare through systematic and complete land certification (hereinafter PTSL). PTSL is the first land registration activity. It is carried out simultaneously for all land registration object throughout the territory of Indonesia includes all the area in one village or sub-districti area that includes the collection and determination of the correctness of both physical and juridicial data.

In the case of dominant land conflicts caused by land title certificates, legal certainty of the certificate is required. Legal certainty is needed as a principle in a rule of law state, Arief Sidharta ever mention his opinion of the elements and principles of a rule of law, grouping into five (5) namely (M. Ramli 2008):

1. Recognition of Human rights;

2. The principle of legal certainty applies;

3. No discrimination; 


\section{Democracy;}

5. The government carries the mandate of the community.

Land registration is carried out to ensure legal certainty in line with the principle point 2 of the Rule of law above, which involves the government and the community. The government with the concept of controlling creates authority in the implementation of government affairs. The government's authority in land registration always improves services for its people. The authority is affected by 3 elements, namely: influence, legal basis, and legal conformity (Fockema 1983). Building the law is a process of determining the choice of interests which become the goals and social values that form the basis for the preparation of legal norms (Ismail 2006). The process of formatting regulation is affected by social context that occur during the process. The process continuously trying to complete the legal products that have been produced (Sudiarawan, Tanaya, and Hermanto 2020).

\section{Comparison of Land Certification in Other Countries}

\section{Singapore}

The registration of land in Singapore is regulated by the Land Titles Act Chapter 157 version 2015 (hereinafter LTA Chapter 157). Due to the Singapore Law Watch, Section 3 Ch. 29 concerning Land Law, it is known that all lands belong to the state and other persons can only own an estate or some lesser interest in the land (Anon n.d.). The ownership of land in Singapore simply can be divided into 2 (two), they are: freehold estate and leasehold estate (Jayanti, Arba, and Hirsanuddin 2017). Simply put, freehold land owners can own the land forever, means that there is no time limit. While, leasehold estate does have an expiry date. Commonly in Singapore there would be a 999-year and 99-year lease.

Back in 2001, the Singapore Land Authority was established with the authority taking a responsibility for land matters in Singapore including land registration. Singapore also known as a country that adopts a positive publication system in terms of registration of land. Hence, the registration of land is very important to them in order to ensure the legal certainty of land ownership.

\section{Malaysia}

In Malaysia, the State authority in terms of alienation of lands is regulated in the Federal
Constitution 1957 and the National Land Code 1965 (hereinafter NLC 1965) (Samsudin et al. 2021). Land ownership is known as the granting of land by the State authority to individuals or bodies (Samsudin et al. 2021). As one of members in ASEAN, Malaysia known to adopt the Torren System (Richard Wu 2011). This system is designed to provide simplicity especially in terms of land registration (Richard Wu 2011).

Just like Singapore, Malaysia also knows two ways of land ownership, inter alia, the disposal through land alienation by granting freehold and leasehold land ownership. While, disposal other than land alienation grants the land reserve, temporary occupation license, to extract and remove rock material permit, and use of air space permit (Samsudin et al. 2021). Hence, the land registration in Malaysia is applied with a simple and effective system in order to providesa high degree of certainty to the parties (Richard Wu 2011).

\section{Mexico}

The land reform was initially granted access to land considered as incomplete property right in Mexico (De Janvry, Gonzalez-Navarro, and Sadoulet 2014). In the twentieth century, the aqrarian question was considered as Mexico's major problems (De Ita 2006). The access to land was constructed with series of turbulent and often with violent series (De Janvry et al. 2014). Back to the colonial regime, land in Mexico was grabbed by an elite from the native indigenous communities in order to concentrated the land in large estates (De Janvry et al. 2014).

The first land reform in Mexico was known to be one of the largest in the world that gradually expropriated and unclaimed land that cover $52 \%$ of the Mexican territory (De Janvry et al. 2014). Later in 1992, the second land reform happened with the objective to strengthen individual property in agrarian sector by providing certificate of ownership of land parcels known as Procede Program (Program for the Certification of Rights to Ejido Lands) (De Janvry et al. 2015). The certification reforms simultaneously help by eliminating restrictions on land sales, land rentals and sharecropping (De Janvry et al. 2015).

\section{Ethiopia}

In Ethiopian, land holding certificates are being issued in four major regiolan states of Ethiopia, namely: Amhara, Southern Nations, Nationalities, and Peoples; Oromiya; and Tigray regions (Qin et al. 2020). Back in 1975, the land tenure system in Ethiopia was 
dominated with strong links to political and class structure along with high regional variation make it more complex (Zhou, Li, and Liu 2020). Recently, the government of Ethiopia granting policy regarding the registration of landholding and certification of landownership (Qin et al. 2020). The government also manage to collect taxes from land users by implementing the land registration policy.

In accordance with it, the presence of a strong demand for rural area land certification among farmers of Ethiopia can be seen as a preliminary evidence as well as willingness to pay for a certificate and higher input use intensities among certificates holders (Qin et al. 2020). However, there still a doubt among farmers who initially believed that land certification was just another politically motivated campaign and only started changing their perspective as they participated in the process and realized the potential usefulness of the land certificates itself. Land certificates serve to secure the right to compensation if land is reallocated and secure the right to the land if there is any disputes (Qin et al. 2020).

\section{CONCLUSION}

The UUPA is a legal product in the field of agriculture that is unification for all Indonesians and revokes the Agrarian provisions in the Dutch East Indies era, especially the domineering principle as mandated by the provisions of Article 33 paragraph (3) of the 1945 Constitution of Indonesia. The law politics of certifying land rights is part of national Agrarian politics aimed at realizing the welfare of the community through registration of land. Various agrarian conflicts that occur in Indonesia are predominantly caused by problems with land certification. Legal certainty through the certification of land rights is the answer to what Agrarian Law politics wants, given that in order to create agrarian politics that makes the community prosperous, protection of the rights inherent in land is needed. Having clear rights will be able to provide increased economic value for land owners and improve the welfare of Indonesia society at large. Comparison of laws related to the regulation and politics of land titling laws in several countries such as Singapore, Malaysia, Mexico, and Ethiopia show the level of awareness of protecting land rights through land rights certification. Certification of land rights is carried out considering the importance of the existence of a certificate as proof of ownership of land that can be used as a sign of ownership, guarantees of compensation rights in case of relocation, as well as proof of ownership in the event of land dispute, as well as provides a high level of certainty to the parties.

\section{REFERENCES}

Aditya, Trias, Eva Maria-Unger, Rohan Bennett, Paul Saers, Han Lukman Syahid, Doni Erwan, Tjeerd Wits, Nurrohmat Widjajanti, Purnama Budi Santosa, and Dedi Atunggal. 2020. "Participatory Land Administration in Indonesia: Quality and Usability Assessment." Land 9(3):79. https://doi.org/10.3390/land9030079

Amiludin, Amiludin. 2018. "Politik Hukum Pertanahan Dan Otonom Daerah (Kebijakan Dan Kewenangan Pemerintah Pusat Dengan Daerah Terkait Pertanahan)." Journal of Government and Civil Society 2(1):19-32. https://doi.org/10.31000/jgcs.v2i1.712

Anggriawan, Fiddy. 2011. "Kronologis Konflik Lahan Di Mesuji Versi Walhi : Okezone Nasional." Okenews.

Anon. n.d. "Ch. 29 Land Law Www.Singaporelawwatch.Sg." Retrieved April 12, 2021 (https://www.singaporelawwatch. sg/About-Singapore-Law/Commercial-Law/ch-29-land-law).

Al Bahriyatul Baqiroh, Nur Faizah. 2019. "Sofyan Djalil Berjanji Tuntaskan Masalah Konflik Lahan - Ekonomi Bisnis.Com."

BAPPENAS, Kementerian PPN /. 2013. "White Paper Kebijakan Pengelolaan Pertanahan Nasional."

Chopra, Surabhi. 2015. "Legislating Safety Nets: Comparing Recent Social Protection Laws in Asia." Indiana Journal of Global Legal Studies 22(2):573-629. https://doi.org/10.2979/indjglolegstu.22.2.573

Choudhury, Nafay. 2017. "Revisiting Critical Legal Pluralism: Normative Contestations in the Afghan Courtroom•." Asian Journal of Law and Society 4(1):229-55. https://doi.org/10.1017/als.2017.2

Djanggih, Hardianto, and Salle. 2017. "Aspek Hukum Pengadaan Tanah Bagi Pelaksanaan Pembangunan Untuk Kepentingan Umum." Pandecta Research Law Journal 12(2):165-72. https://doi.org/10.15294/pandecta.v12i2.11677

Ellickson, Robert C. 1993. "Property in Land." Yale Law Journal 1315-1400. https://doi.org/10.2307/796972

Fadli, Ardiansyah. 2020. "Konflik Pertanahan 9.000 Kasus, Pengamat Sarankan Pemerintah Bagi-Bagi Tanah Halaman All - Kompas.Com."

Fockema, Andreae. 1983. "Kamus Istilah Hukum BelandaIndonesia."

Gilbert, Jérémie. 2013. "Land Rights as Human Rights - Sur International Journal on Human Rights." International Journal on Human Rights 18.

Ginting, Darwin. 2011. "Reformasi Hukum Tanah Dalam Rangka Perlindungan Hak Atas Tanah Perorangan Dan Penanam Modal Dalam Bidang Agrobisnis." Jurnal Hukum Ius Quia Iustum 18(1):63-82. https://doi.org/10.20885/iustum.vol18.iss1.art4

Hajati, Sri, Sri Winarsi, Agus Sekarmadji, and Oemar Moechtar. 2020. Buku Ajar Politik Hukum Pertanahan. Surabaya: Airlangga University Press.

Handoko, Widhi. 2011. "Rekonstruksi Sistem Birokrasi Pertanahan Menuju Konsep Keadilan Dalam Kerangka Politik Hukum Agraria: Tinjauan Terhadap Implementasi Ketetapan Mpr RI No. Ix/Mpr/2001." Jurnal Konstitusi 4(2):139-62.

Harsono, Boedi. 1994. Hukum Agraria Indonesia: Sejarah Pembentukan Undang-Undang Pokok Agraria, Isi Dan Pelaksanaannya. Jakarta: Djambatan.

Herrayani, Dessy Ghea, Lucky Faradila Soraya, and Oemar Mocthar. 2019. "Eksistensi Hak Komunal Masyarakat Hukum Adat Dalam Kebijakan Penataan Aset Reforma Agraria." Kertha Patrika 41(3):283-99. 
Human Rights Watch. n.d. "Land Rights | Human Rights Watch."

Ismail, Nurhasan. 2006. "Perkembangan Pilihan Kepentingan, Nilai Sosial Dan Asas Hukum Dalam Hukum Pertanahan." Mimbar Hukum 18(2006).

Ismail, Nurhasan. 2012. "Arah Politik Hukum Pertanahan Dan Perlindungan Kepemilikan Tanah Masyarakat." Jurnal Rechts Vinding: Media Pembinaan Hukum Nasional 1(1):3351.

https://doi.org/10.33331/rechtsvinding.v1i1.105

De Ita, Ana. 2006. "Land Concentration in Mexico after PROCEDE." Promised Land: Competing Visions of Agrarian Reform 14864.

De Janvry, Alain, Kyle Emerick, Marco Gonzalez-Navarro, and Elisabeth Sadoulet. 2015. "Delinking Land Rights from Land Use: Certification and Migration in Mexico." American Economic Review 105(10):3125-49. https://doi.org/10.1257/aer.20130853

De Janvry, Alain, Marco Gonzalez-Navarro, and Elisabeth Sadoulet. 2014. "Are Land Reforms Granting Complete Property Rights Politically Risky? Electoral Outcomes of Mexico's Certification Program." Journal of Development Economics 110:216-25. https://doi.org/10.1016/j.jdeveco.2013.04.003

Jayanti, R. A. Andria, M. Arba, and Hirsanuddin Hirsanuddin. 2017. "Comparative Study of Land Registration in the State of the Republic of Indonesia and the Republic of Singapore." Khairun Law Journal 1(1):22-32.

L Purwaka, Tommy Hendra. 2016. POLITIK HUKUM. Jakarta: Pusat Penelitian Badan Keahlian DPR RI 2016.

Lindbeck, Assar. 2006. The Welfare State-Background, Achievements, Problems. IFN working paper.

M. Ramli, Ahmad. 2008. "Peranan Hukum Dalam Penegakan HakHak Dasar Rakyat Pasca Satu Dekade Reformasi." Majalah Hukum Nasional.

Muhammad, Arisaputra Ilham. 2015. "Reforma Agraria Di Indonesia." Jakarta. Penerbit Sinar Grafika.

Paino, Christopel. 2015. "Tambang Rugikan Masyarakat Donggala : Mongabay.Co.Id." Mongabay.

Parlindungan, Adi Putera. 1997. Komentar Atas Undang-Undang Perumahan Dan Pemukiman \& Undang-Undang Rumah Susun. Bandung: Mandar Maju.

Petroski, Karen. 2015. "Legal Fictions and the Limits of Legal Language." Pp. 131-56 in Legal fictions in theory and practice. Springer. https://doi.org/10.1007/978-3-319-09232-4 7

Qin, Ming, Wensheng Lin, Jing Li, Zhou Yu, and Cheryl Wachenheim. 2020. "Impact of Land Registration and Certification on Land Rental by Chinese Farmers." Land Use Policy 99:104875. https://doi.org/10.1016/j.landusepol.2020.104875

Rahman, H. Abd, and S. H. Baso Madiong. 2017. Politik Hukum Pertanahan. Vol. 1. Celebes Media Perkasa.
Rahmi, Elita. 2010. "Eksistensi Hak Pengelolaan Atas Tanah (HPL) Dan Realitas Pembangunan Indonesia." Jurnal Dinamika Hukum 10(3):339-48. https://doi.org/10.20884/1.jdh.2010.10.3.104

Richard Wu. 2011. "Implementation of Land Title Registration System in Malaysia Current Offers." Malayan Law Journal Articles 1(1):1-11.

Roux, Lani Maré. 2013. "Land Registration Use: Sales in a StateSubsidised Housing Estate in South Africa." Graduate Studies.

Samsudin, S., N. A. Ibrahim, R. Suratman, and M. Z. Adnan. 2021. "Land for Indigenous People: Ownership Conflicts and Government Interventions in Kampung Bawong, Perak, Malaysia." IOP Conference Series: Earth and Environmental Science 683(1):012124. https://doi.org/10.1088/1755-1315/683/1/012124

Silviana, Ana. 2012. "Kajian Tentang Kesadaran Hukum Masyarakat Dalam Melaksanakan Pendaftaran Tanah." Pandecta: Jurnal Penelitian IImu Hukum (Research Law Journal) 7(1). https://doi.org/10.15294/pandecta.v7i1.2371

Soetrisno, Lukman. 1995. Memuja Masyarakat Partisipastif. Yogyakarta: Kanisius.

Sudiarawan, Kadek Agus, Putu Edgar Tanaya, and Bagus Hermanto. 2020. "Discover the Legal Concept in the Sociological Study." Substantive Justice International Journal of Law 3(1):94-108. https://doi.org/10.33096/sjijl.v3i1.69

Sulistio, Meiliyana. 2020. "Politik hukum pertanahan Di Indonesia." Jurnal Education and Development 8(2):105.

Sumardjono, Maria S. 2006. Kebijakan Pertanahan: Antara Regulasi Dan Implementasi. Jakarta: Penerbit Buku Kompas.

Syahri, Ryan Alfi. 2014. "Perlindungan Hukum Kepemilikan Hak Atas Tanah."

Tirthayasa, I. Made. 2013. "Tanah Kuburan Karang Rupit Milik Temukus - ANTARA News Bali." Antara Bali.

Triari, Putri, Kali Jones, and Ni Gusti Ayu Dyah Satyawati. 2017. "Indigenous People, Economic Development and Sustainable Tourism: A Comparative Analysis between Bali, Indonesia and Australia." Udayana Journal of Law and Culture. https://doi.org/10.24843/UJLC.2017.v01.i01.p02

Wardhana, Seto. 2020. "Government Aims to Certify All State Lands by 2022 - Business - The Jakarta Post." Thejakartapost.Com.

Wicaksono, Pribadi. 2019. "2025, Pemerintah Targetkan 126 Juta Bidang Tanah Tersertifikasi - Bisnis Tempo.Co." Tempo.Co.

William Benu, Victor. 2020. "Membaca Hak Publik Di Kantor Pertanahan - Ombudsman RI."

Zhou, Yang, Xunhuan Li, and Yansui Liu. 2020. "Rural Land System Reforms in China: History, Issues, Measures and Prospects." Land Use Policy 91:104330. https://doi.org/10.1016/j.landusepol.2019.104330

Received on 06-02-2021

Accepted on 20-04-2021

Published on 26-04-2021

https://doi.org/10.6000/1929-4409.2021.10.106

(c) 2021 Yasa et al.; Licensee Lifescience Global.

This is an open access article licensed under the terms of the Creative Commons Attribution Non-Commercial License (http://creativecommons.org/licenses/by-nc/3.0/) which permits unrestricted, non-commercial use, distribution and reproduction in any medium, provided the work is properly cited. 